Nilai-Nilai Utama Karakter Spiritual Keagamaan Dan.....

\title{
NILAI-NILAI UTAMA KARAKTER SPIRITUAL KEAGAMAAN DAN INTEGRITAS DALAM KISAH AL-QUR'AN
}

\author{
Khairul Khalqi \\ Program Pascasarjana \\ Universitas Islam Negeri (UIN) Sunan Kalijaga Yogyakarta \\ khalqi457@gmail.com
}

\begin{abstract}
Various dynamics in leadership that occur in Indonesia, human characters that are very different from one another that happened before, it is important to discuss various examples in the story that Allah described in the Qur'an that can be read for example. In this study using the literature method. In this research, we can understand the figures that describe God in the Al-Qur'an who have religious characteristics and figures who have integrity. This can be seen in the story of Lukman al-Hakim with the verdict which has the story of ma'rifatullah (monotheism) which is illustrated in several verses in the Koran, where Lukman teaches children not to associate partners with Allah and worship only for Allah, therefore can help prayers in accordance with the commands of Allah SWT. Then take a human who has the character of integrity (honest) the writer takes on the story of the Prophet Yusuf AS illustrated in the Al-Qur'an where the compilation is slandered by Zulaikha but he is always honest and never succeeded, so that he was the Prophet Yusuf AS, can be chosen according desire because of the honesty he has.
\end{abstract}

Keyword: Character values, religious spiritual, integrity.

\begin{abstract}
Abstrak
Berbagai dinamika dalam kepemimpinan terjadi di Indonesia, karakter manusia yang sangat berbeda antara satu dengan yang lainnya mengakibatkan hal tersebut terjadi, penting untuk kita mengetahui berbagai sipat keteladanan dalam kisah yang Allah gambarkan di alQur'an yang tentunya patut untuk dicontoh. Dalam penelitian ini menggunakan metode kepustakaan (library research). Dalam penelitian ini dapat kita ketahui tokoh yang digambarkan Allah dalam al-Qur'an yang memiliki sifat spiritual keagamaan dan tokoh yang memiliki sifat integritas. Hal ini dapat kita lihat dalam kisah Lukman al-Hakim dengan anaknya yang memiliki kisah ma'rifatullah (tauhid) yang tergambar dalam beberapa ayat pada al-Quran, dimana Lukman mengajari anaknya untuk tidak menyekutukan Allah dan menyembah hanya kepada Allah, selain itu melaksanakan shalat sesuai dengan perintah Allah SWT. Kemudian kisah manusia yang memiliki karakter integritas (jujur) penulis mengambil pada kisah Nabi Yusuf AS yang tergambar dalam alQuran yang dimana ketika di fitnah oleh Zulaikha namun dia selalu jujur dan tidak pernah berbohong, sehingga ia Nabi Yusuf AS, dapat diangkat menjadi pemimpin karena kejujuran yang dia miliki.
\end{abstract}

Kata kunci: Nilai-nilai karakter, spiritual keagamaan, integritas. 
Khairul Khalqi

PENDAHULUAN

Spritual keagamaan sebagai salah satu pondasi yang harus dimiliki oleh setiap manusia agar menjadikan jiwa sebagai insanul kamil $^{1}$ dalam konteks kehidupan sesuai dengan syari'at yang telah ditentukan oleh Allah Swt agar jiwa tetap terjaga dalam keadaan fitrah dan suci. Kaitanya terhadap fitrah yang menjadi basis utama yang tentu berhubungan dengan Rohani yang dimaksud disini adalah aspek manusia yang selain jasmani dan akal logika manusia yang tentu masih belum jelas. Para ilmuan sufi bisanya rohani pada hakikatnya berbicara tentang hati (qalb) jiwa yang bersih. ${ }^{2}$

Jika dilihat dalam konteks di Indonesia bahwa, Indonesia merupakan suatu bangsa yang besar dengan memiliki berbagai potensi sumber dayanya. Sebagai bangsa yang besar Indonesia memiliki cita-cita mensejahtrakan kehidupan bangsa sesuai dengan apa yang di syari'atkan dalam Islam. Namun hal tersebut tidak senada dengan norma-norma yang telah ditetapkan, hal ini sebenarnya masih belum terwujud secara maksimal tentu disebabkan ada beberapa banyak faktor yang menyebabkan keadaan ini Misalnya, korupsi, kurangnya moralitas manusianya, dan lain sebagainya. Kasus korupsi telah menjadi konsumsi media publik baik cetak maupun elektronik. Setiap hari hampir media publik tidak pernah absen menyuguhkan berita tentang korupsi. ${ }^{3} \mathrm{Hal}$ ini yang menjadi problematika yang kian kini masih menjadi bahan yang harus dioptimalkan untuk menghidupkan nilai-nilai tersebut. Kemampuan untuk mengontrol emosi adalah keterampilan penting yang dibutuhkan. ${ }^{4}$

"The ambitions that most parents have for their children naturally include the development of important moral dispositions." Pada hakikatnya pembentukan moral yang dilakukan oleh orang tua terhadap anak-anaknya sudah menjadi bagian dalam proses

\footnotetext{
${ }^{1}$ Kajian Insanul ini merupakan salah satu ciri manusia yang hidupnya menjadi baik. Ibn al-arabi merumuskan konsep insan al-kamil dalam beberapa bagian yaitu manusia, alam dan Allah swt. Manusia Paripurna (Insan Kamil) merupakan roh alam semesta. Sedangkan roh alam semesta sebagai ladah dan tempat bagi insan Kamil, yang mana baik alam maupun manusia cermin dari wujud Allah Swt konsepnya adalah dalam konteks kehidupa memberikan yang terbaik sesuai syari'at yang telah ditentukan. Baca selengkapnya. Jagad Batin IBNU AL-ARABI, Menuju Manusiadan Kewalian Paripurna, Penerjemah, Al-Arabi, (Yogyakarta: Institute of Nation Development Studies (INDeS), 2016), hlm. vi

${ }^{2}$ Ahmad Tafsir, Ilmu Pendidikan Dalam Perspektif Islam, (Bandung: PT Remaja Rosdakarya, 2004), hlm.44

3 Sukadari, Mahilda Dea Komalasari, and Ahmad Mabruri Wihaskoro, "Evektivitas Penanaman Nilai Integritas Pada Sisiwa SD Melalui Buku Wayang Pandawa Bervisi Antikorupsi,” Integritas Vol. 4, no. 1 (2018): 218.

${ }^{4}$ Budy Menawar, Rachman, Pendidikan Karakter Dengan Pendekatan Living Vales Education, ( Jakarta: The Asia Foundation, 2019), hlm. xxvi

${ }^{5}$ Daniel K. Lapsley and Darcia Nervaez, Character Education, (New York: Wiley).
}

Falasifa, Vol. 10 Nomor 2 September 2019 | 161 
Nilai-Nilai Utama Karakter Spiritual Keagamaan Dan.....

pembentukan moral untuk menjadikan sebagai anak yang cerdas yang dapat dikatakan sebagai insan kamil. Oleh karenanya orang tua memposisikan diri sebagai pendidik dalam konteks mampu melahirkan dan membentuk anak itu sebagai manusia seutuhnya. Namun dengan semua keinginan dan usaha itu masih banyak orang tua yang belum mampu membentuk karakter anak sesuai dengan apa yang diidam-idamkan yang dapat kita sebut sebagai insan kamil. Hal ini mengakibatkan banyak terjadi problematika yang terjadi dalam menjalani aktifitas sehari-hari atau bersosial, tergambar dengan banyaknya manusia yang masih memiliki sifat korupsi serta krisis moral seperti yang telah disebutkan sebelumnya.

Kasus korupsi telah menjadi konsumsi media publik baik cetak maupun elektronik. Setiap hari hampir media publik tidak pernah absen menyuguhkan berita tentang korupsi. ${ }^{6}$ Penuntasan korupsi yang telah dilakukan masih terlihat belum bisa sepenuhnya teratasi, hal ini dikarenakan masih banyaknya manusia yang berbuat hanya karena adanya keinginan untuk dilihat oleh orang lain ataupun berbuat katena suatu keharusan untuk mengerjakannya. Hal ini tentu sangat membutuhkan peminimalisiran yang lebih mendasar. Dengan penanaman nilai-nilai moralitas yang mendasar akan bisa meminimalisir berbagai kejahatan yang terjadi seperti korupsi.

Oleh karenanya, diharapkan manusia memiliki karakter spiritualitas keagamaan dalam hidupnya, sehingga dalam berkegiatan atau bekerja akan merasa selalu diawasi oleh Allah SWT. Sehingga dengan memiliki ketauhidan yang tinggi pada penciptanya, akan lebih mengurangi hal yang negatif dalam diri manusia. Selain nilai spiritual keagamaan (ketauhidan), untuk lebih meminimalisir hal tersebut, dibutuhkan juga dalam diri manusia nilai integritas, sehingga dalam menjalankan amanah ataupun pekerjaan akan dengan rasa tulus, bekerja dengan baik dan tidak semata-mata karena ingin dilihat oleh orang lain ataupun bekerja hanya karena adanya undang-undang yang mengikatnya.

Dengan demikian tulisan ini akan mengkaji dan menganalisis nilai-nilai spiritual keagamaan yang dimana dalam kontek tersebut mempunyai integrasi yang termuat dalam kisah al-Quran. Oleh karenanya, substansi dari pembahasan tulisan ini memetakan secara signifikansi dan menjelaskan secara spesifik bagaimana konsep karakter spiritual keagamaan dan integritas sekaligus implementasi dalam kisah al-Quran.

${ }^{6}$ Sukadari, Mahilda Dea Komalasari, and Ahmad Mabruri Wihaskoro, "Evektivitas Penanaman Nilai Integritas Pada Sisiwa SD Melalui Buku Wayang Pandawa Bervisi Antikorupsi," Integritas Vol. 4, no. 1 (2018): 218.

Falasifa, Vol. 10 Nomor 2 September 2019 | 162 


\section{Khairul Khalqi}

\section{PEMBAHASAN}

\section{A. Hakikat Nilai Spiritualitas Keagamaan Berintikan Marifatullah (Tauhid)}

Memandang hakikat spiritual keagamaan khususnya dalam Islam tidak akan terlepas dari sebuah syariat. Syariat merupakan ajaran/tuntunan. Syariat Islam berarti ajaran atau tuntunan dari Allah SWT yang diturunkan kepada Nabi/Rosul-Nya untuk dijalankan di muka bumi. Dasar dari syariat adalah al-Qur'an dan al-Hadits sebagai contoh mengaplikasikan dalam kehidupan umatnya. Dasar syariat Islam adalah tauhid, yaitu mengesakan Allah serta tidak menyekutukan Dia dengan suatu apapun. Tauhid inilah ruh yang menjadikan spiritual Islam dalam mengarungi hidup dan kehidupan di dunia ini, dan tidak dapat terwujud nilai spiritual seseorang kecuali dengan naungan ketuhanan ini.

Bagi seorang muslim memahami ajaran Islam suatu kewajiban, maka harus mengembalikan persoalan yang dimiliki kepada al-Qur'an dan as-Sunnah sebagai pedoman hidup. Hakikat merupkan suatu yang harus menjadi inti amaliah syariat sehingga hakikat itu tidak berdiri sendiri, tapi ia adalah nilai ruh syariat itu sendiri.

Tauhid menurut harfiah berasal dari kata wahid yang berarti satu. Sedangkan menurut istilah agama Islam, tauhid itu ialah keyakinan tentang satu atau Esanya Tuhan, segala pikiran dan teori berikut dalil-dalilnya yang menjurus kepada kesimpulan bahwa Tuhan itu satu disebut ilmu tauhid. ${ }^{7}$

Menurut Maragustam yang dikutib oleh Hanafi, tauhid menurut bahasa adalah meng-Esakan, Sedangkan menurut istilah syariat ialah meyakini keesaan Allah. Sedangkan macam-macam tauhid itu sendiri meliputi tauhid rububiyah, tauhid uluhiyah, dan tauhid asma' wa sifat. ${ }^{8}$ Dalam pandangan Zainuddin pembagian dalam ilmu tauhid menjadi tiga yaitu tauhid uluhiyah, tauhid rububiyah, dan tauhid ubudiyah. Pertama, tauhid Uluhiyah ialah percaya sepenuhnya, bahwa Allah-lah yang berhak menerima semua peribadatan makhluk, dan hanya Allah sajalah yang sebenarnya dan yang harus disembah. ${ }^{9}$ Hal ini sesuai dengan firman Allah SWT:

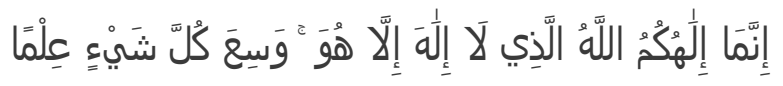

\footnotetext{
${ }^{7}$ Zainuddin, Ilmu Tauhid Lengkap (Jakarta: Rineka Cipta, 1992), 1.

${ }^{8}$ Imam Hanafi, "Urgensi Penanaman Nilai Karakter Spiritual Keagamaan dan Integritas dalam Dunia Pendidikan," An-Nuha Vol. 4, no. 2 (2017): 141.

${ }^{9}$ Zainuddin, Ilmu Tauhid Lengkap, 17.
} 
Nilai-Nilai Utama Karakter Spiritual Keagamaan Dan.....

Artinya: "Sesungguhnya Tuhanmu hanyalah Allah, yang tidak ada Tuhan selain Dia". (Q.S. Taahaa: 98). ${ }^{10}$

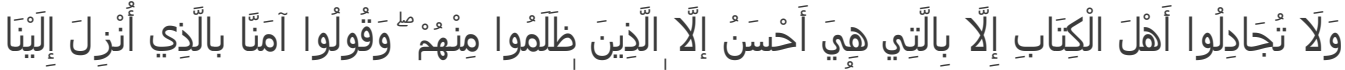

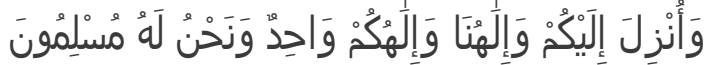

Artinya: "Tuhan Kami dan Tuhanmu adalah satu; dan Kami hanya kepada-Nya berserah diri". (Q.S. Al-Ankabut: 46). ${ }^{11}$

Dengan demikian dapat kita simpulkan bahwa tauhid uluhiyah merupakan keyakinan tentang Allah SWT. sebagai tuhan satu-satunya, baik zat-Nya, maupun sifat dan perbuatan-Nya. Kedua, tauhid Rububiyah ialah suatu kepercayaan, bahwa yang menciptakan alam dunia beserta isinya ini, hanyalah Allah sendiri tanpa bantuan siapapun. ${ }^{12}$ Dalam hal ini sesuai dengan firman Allah SWT:

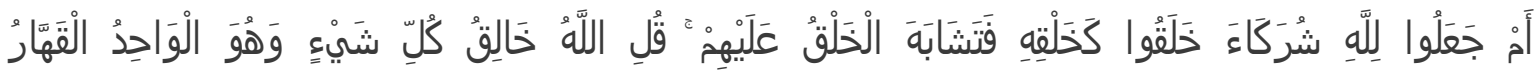

Artinya: "Katakanlah: "Allah adalah Pencipta segala sesuatu dan Dia-lah Tuhan yang Maha Esa lagi Maha Perkasa". (Q.S. Ar-Ra'd: 16). ${ }^{13}$

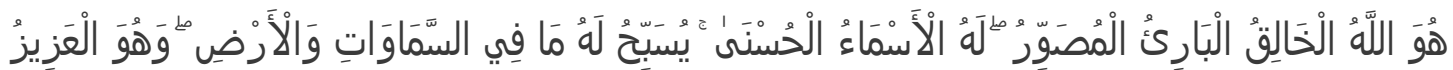
الْحَكِيٌْ

Artinya: "Dialah Allah yang Menciptakan, yang Mengadakan, yang membentuk Rupa". (Q.S. Al-Hasyr: 24). ${ }^{14}$

Dari ayat-ayat tersebut dapat diambil pengertian, bahwa kata "Illah" itu berarti "Tuhan" dan kata "Rab" berarti "Tuhan yang telah menciptakan, mengatur dan mengurus alam semesta". Sedangkan "Rububiyah" adalah nisbah dari Rab. Sehingga Tauhid Rububiyah berarti menyakini bahwa Allah SWT. sebagai Tuhan satu-satunya yang menguasai dan mengurus serta mengatur alam semesta. ${ }^{15}$

Ketiga, tauhid Ubudiyah ialah suatu keyakinan bahwa tidak ada yang berhak disembah mendapat pengabdian (ibadah) dari kita selain Allah SWT. Tauhid Ubudiah disini berarti suatu penyembahan kepada Allah sebagai suatu ketaatan, kepatuhan dan

\footnotetext{
${ }^{10}$ Enang Sudrajat, Syatibi, and Abdul Aziz Sidqi, Al-Qur'an Tajwid dan Terjemahnya Dilengkapi dengan Asbabun Nuzul dan Hadits Sahih (Bandung: Syigma Examedia Arkanleema, 2007), 318.

${ }^{11}$ Ibid., 402.

12 Zainuddin, Ilmu Tauhid Lengkap, 20.

${ }^{13}$ Sudrajat, Syatibi, and Sidqi, Al-Qur'an Tajwid dan Terjemahnya Dilengkapi Dengan Asbabun Nuzul dan Hadits Sahih, 251.

${ }^{14}$ Ibid., 548.

15 Zainuddin, Ilmu Tauhid Lengkap, 21.
}

Falasifa, Vol. 10 Nomor 2 September 2019 | 164 


\section{Khairul Khalqi}

ketundukan antara hamba dengan Tuhannya, antara makhluk dengan Khaliqnya. ${ }^{16}$ Dalam hal ini penyembahan kepada Allah sesuai dengan fifman-Nya:

$$
\text { وَمَا خَلَقْتُ الْجِنَّ وَالْإِنْسَ إِلَّا لِيَعْبُونِ }
$$

Artinya: "dan aku tidak menciptakan jin dan manusia melainkan supaya mereka mengabdi kepada-Ku". (Q.S. Az-Zaariyat: 56). ${ }^{17}$

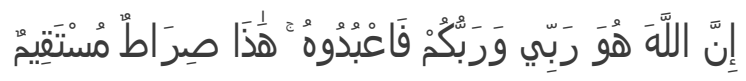

Artinya: "Sungguh, Allah, Dia Tuhanku dan Tuhanmu, Maka sembahlah Dia. Ini adalah jalan yang lurus". (Q.S. Az-Zukhruf: 64). ${ }^{18}$

Ketiga macam tauhid itu satu sama lain saling berkaitan, artinya bahwa sahnya salah satu dari ketiga tauhid itu bila yang lain juga sah, sehingga tidak akan bisa sempurna ketauhidan bila ada diantara salah satu dari bagian tauhid itu tidak diyakini atau dijalankan.

Dalam peribadatan yang dilakukan oleh seorang hamba, tentu antara satu orang dengan orang yang lainnya akan memiliki perbedaan, sehingga dengan perbedaan tersebut dapat dikategorikan bahwa ibadah yang dilakukan memiliki tingkatan dan dalam hal ini pemakalah mengambil dasar dari tingkatan tersebut dari hadits ke-dua dalam kitab hadits Arbain an-Nawawi yaitu, Islam, Iman, dan Ihsan. ${ }^{19}$ Hal ini dapat kita jabarkan sesaca singkat. Pertama, Islam merupakan kesaksian seseorang bahwa tiada tuhan selain Allah dan Nabi Muhammad adalah utusan Allah, mengerjakan shalat, menunaikan zakat, berpuasa dalam bulan ramadhan, dan berhaji ke Baitullah jika mampu. ${ }^{20}$ Dengan hal ini bahwa Islam mengandung makna memasrahkan diri kepada Allah, tunduk serta taat melakukan semua perintah Allah dan menjauhi larangan-Nya.

Kedua, Iman ialah kepercayaan dalam hati meyakini dan membenarkan adanya Tuhan dan membenarkan apa-apa yang dibawa oleh Nabi Muhammad SAW. ${ }^{21}$ Dengan demikian iman juga dapat dikatakan sebagai suatu yang diucapkan dengan lisan, diyakini

\footnotetext{
${ }^{16}$ Ibid., 22.

${ }^{17}$ Sudrajat, Syatibi, and Sidqi, Al-Qur'an Tajwid dan Terjemahnya Dilengkapi dengan Asbabun Nuzul dan Hadits Sahih, 523.

${ }^{18}$ Ibid., 494.

19 Al-Imam an-Nawawi and Al-Hafizh Ibnu Rajab al-Hambali, Hadits Arba'in Nawawiyyah Plus (Matan Jami'ul-'Ulum Wal-Hikmah), Cet. 4 (Yogyakarta: Maktabah Al-Hanif, 2009), 24-26.

${ }^{20}$ Ibid., 25.

${ }^{21}$ Zainuddin, Ilmu Tauhid Lengkap, 67.
} 
Nilai-Nilai Utama Karakter Spiritual Keagamaan Dan.....

dalam hati, dan diamalkan dalam bentuk perbuatan. Sehingga keimanan itu tidak hanya sebatas meyakini namun juga harus diimplementasikan dalam bentuk perbuatan dalam kehidupan. Jika kita melihat lebih lanjut iman merupakan cahaya yang menerangi agar berprilaku lurus di jalan kebajikan serta mendapat nikmat di hari kemudian. ${ }^{22}$

Ketiga, Ihsan adalah apabila seseorang beribadah kepada Allah maka seakan-akan seseorang tersebut melihat-Nya dan jika seseorang tersebut tidak mampu melihat-Nya maka sesungguhnya Allah melihat seseorang tersebut. ${ }^{23}$ Ihsan merupakan tingkatan ibadah paling tinggi. Ihsan merupakan kesadaran penuh terhadap kehadiran Allah dalam diri serta selalu mengawasi kita. Apabila hal ini tertanam dalam diri seseorang, maka setiap perbuatan yang dilalukan akan dijalankan dengan penuh tanggung jawab, serta menjaga diri dari perbuatan yang tidak diridhai oleh Allah SWT. ${ }^{24}$

Dari pemaparan tiga bentuk tauhid tersebut dapat kita ketahui bahwa hal demikian itu harus dimiliki oleh seorang yang muslim, tidak hanya demikian, melainkan juga selalu berusaha mencapai peribadatan yang paling tinggi sebagaimana yang telah dipaparkan di atas. Pada hakikatnya spiritualitas ialah pandangan pribadi dan prilaku yang mengekspresikan rasa keterkaitan, tujuan hidup, makna hidup dan kesadaran ke dimensi transendental (Yang Maha Tinggi) atau untuk sesuatu yang lebih besar dari diri sehingga mengerti arti dan tujuan hidup. ${ }^{25}$ Dengan demikian tentu sangat penting untuk menanamkan nilai-nilai keislaman yang membangun terbentuknya kesadaran Ilahiyah, yaitu sebuah kesadaran yang menganggap bahwa semua niat, kata dan perbuatan meskipun berlandaskan pada penghayatan atas ajaran agama yang kokoh. ${ }^{26}$

Dengan demikian, jika kita melihat pandangan dari Prof. Maragustam, ia berpandangan bahwa spiritual keagamaan atau keimanan adalah inti dari hati nurani moral (moral consequence), dan pada hakikatnya hati nurani moral inilah yang menjadi kekuatan ruhaniyah dan keimanan yang memberi semangat kepada seseorang untuk berbuat terpuji

\footnotetext{
${ }^{22}$ Maragustam, Mencetak Pembelajar Menjadi Insan Paripurna (Yogyakarta: Nuha Litera, 2010), 151.

23 an-Nawawi and al-Hambali, Hadits Arba' in Nawawiyyah Plus (Matan Jami'ul-'Ulum Wal-Hikmah), 26.

24 Hanafi, "Urgensi Penanaman Nilai Karakter Spiritual Keagamaan Dan Integritas Dalam Dunia Pendidikan," 143.

${ }^{25}$ Maragustam, Filsafat Pendidikan Islam Menuju Pembentukan Karakter Menghadapi Arus Global, Cet. 2 (Yogyakarta: Kurnia Kalam Semesta, 2016), 255.

26 Hanafi, "Urgensi Penanaman Nilai Karakter Spiritual Keagamaan Dan Integritas Dalam Dunia Pendidikan," 145.

Falasifa, Vol. 10 Nomor 2 September $2019 \mid 166$
} 


\section{Khairul Khalqi}

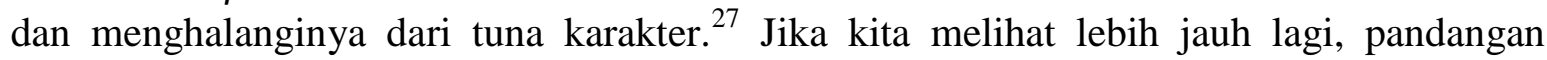
mengenai moral consequence ini merupakan suatu penentu dari setiap yang akan dilakukan oleh manusia dan sebagai penentu dari arah perbuatan atau prilaku manusia yang dimana hal ini bersumber pada hati. Hati pada dasarnya memiliki kekuatan untuk mengatur dan mendorong dari setiap prilaku manusia ke arah yang lebih ditekankan positif atau negatif. ${ }^{28}$

Jika kita melihat pandangan dari Ahmad Amin (1975) yang dikutip oleh Prof. Maragustam, tingkatan suara hati terbagi menjadi tiga yaitu:

1. Perasaan melakukan kewajiban karena takut kepada manusia.

Pada tingkatan ini faktor negatif dari tingkatan ini ialah seseorang suka jatuh dalam lembah kehinaan, bila berada sendirian dan jauh dari penglihatan manusia, kemudian bila terpengaruh dengan lingkungan yang buruk, ia tentu tidak malu akan berbuat keji dan tidak takut penghinaan orang untuk melakukan semua kejahatan, dan jika sistem aturan lemah, maka ia akan melakukan berbagai kejahatan tanpa batas. Sedangkan sisi positifnya, jika ia dikawal dengan peraturan yang ketat, maka ia akan melakukan yang terbaik. ${ }^{29}$

2. Perasaan mengharuskan mengikuti apa yang diperintahkan oleh undang-undang, meskipun sendirian atau dimuka orang banyak.

Perasaan yang mengharuskan mengikuti apa yang diperintahkan undangundang, meskipun sendirian atau didepan orang banyak. Dalam hal ini seseorang akan patuh kepada undang-undang agar terhindar dari siksaan. Namun jika ada celah dalam undang-undang tersebut, ia akan melakukan kejahatan karena terhindar dari menyalahi aturan. ${ }^{30}$

3. Perasaan seharusnya mengikuti apa yang dipandang benar oleh dirinya berbeda dengan pendapat orang lain atau sesuai, menyalahi undang-undang atau berbeda.

\footnotetext{
${ }^{27}$ Maragustam, Filsafat Pendidikan Islam Menuju Pembentukan Karakter Menghadapi Arus Global, 256.

${ }^{28}$ Dalam diri Manusia memiliki potensi positif dan negatif, jika potensi negatif lebih ditekan, maka dalam perbuatan yang akan muncul yakni potensi negatif, namun jika potensi positif yang lebih ditekankan maka yang akan muncul ialah potensi yang bersifat positif. Disampaikan oleh Prof. Maragustam dalam kegiatan perkuliahan Pendidikan Nilai dan Spiritual Islam kelas reguler A, Pascasarjana, Psikologi Pendidikan Islam, UIN Sunan Kalijaga Yogyakarta, tanggal 13 Maret 2019.

${ }^{29}$ Maragustam, Filsafat Pendidikan Islam Menuju Pembentukan Karakter Menghadapi Arus Global, 256257.

${ }^{30}$ Ibid., 257.
}

Falasifa, Vol. 10 Nomor 2 September 2019 | 167 
Nilai-Nilai Utama Karakter Spiritual Keagamaan Dan.....

Pada tingkatan inilah yang dapat dikatakan memiliki karakter. Dimana pada tingkatan ini harus diberdayakan secara terus menerus dengan pengisian nilai-nilai spiritual keagamaan (ma'rifatullah) sehingga suara batin menjadi kuat dan tahan uji terhadap pergeseran nilai. Dengan demikian, meskipun undang-undang lemah ataupun ada celah untuk dilangar, sekalipun tidak ada orang lain yang dapat melihatnya bila melakukan kejahatan, ia tetap melakukan yang terbaik sesuai dengan nilai-nilai yang sudah tertanam dan menjadi karakter dalam dirinya. ${ }^{31}$

\section{B. Hakikat Nilai Integritas (Kejujuran-Amanah)}

Sebelumnya telah kita ketahui nilai spiritual keagamaan, sehingga lebih jauh lagi kita akan bahas mengenai nilai integritas. Integritas diri bermakna keterpaduan diri berbagai unsur atau dimensi dasar diri manusia. Unsur atau dimensi dasar tersebut menyangkut baik fisik, sosial, maupun mental-spiritual (kejiwaan), sehingga integritas diri merujuk pada keterpaduan sinergis dan saling mendukung antara berbagai unsur atau dimensi dasar diri manusia yang berlangsung secara konsisten dan berkesinambungan. Integritas disini lebih dipahami sebagai konsistensi antara tindakan dan nilai yang dianut, konsistensi antara sikap, perkataan dan perbuatan. Orang yang memiliki integritas adalah orang yang hidup sejalan dengan nilai-nilai yang dianutnya. ${ }^{32}$ Dengan demikian di dalam nilai integritas mengandung kejujuran serta amanah yang dimana kedua nilai ini sangat-lah fundamental dan penting untuk dimiliki oleh manusia.

Jujur merupakan suatu keadaan yang dimana seseorang memiliki keterbukaan dengan apa yang dipikirkan dan apa yang ada dalam hatinya. ${ }^{33}$ Kejujuran diartikan sebagai sifat jujur, ketulusan hati dan kelurusan hari, yang dapat dilihat dan diukur pelalui prilaku. Sehingga jujur dapat diartikan sebagai tidakan yang seimbang antara perkataan dan perbuatan yakni mengatakan apa yang dilakukan dan melakukan apa yang dikatakan. ${ }^{34}$

\footnotetext{
31 Ibid.

${ }^{32}$ Antonius Atosokhi Gea, "Integritas Diri: Keunggulan Pribadi Tangguh," Character Building Journal Vol. 3, no. 1 (2006): 17.

${ }^{33}$ Yohanes Probo Dwi S, "Hubungan Antara Nilai Kejujuran Dan Pribadi Yang Otentik Dengan Perilaku Mahasiswa Universitas Bunda Mulia," Psibernetika Vol. 8, no. 2 (2015): 140.

34 Fadillah, "Kejujuran Salah Satu Pendongkrak Pendidikan Karakter Di Sekolah," Jurnal Visi Ilmu Pendidikan (n.d.): 969.
}

Falasifa, Vol. 10 Nomor 2 September 2019 | 168 


\section{Khairul Khalqi}

Selain itu kejujuran dalam tatanan kehidupan masyarakat disepakati sebagai tolak ukur kebaikan seseorang dalam kehidupan sehari-harinya, dan juga merupakan pondasi dalam rangka menciptakan kehidupan yang harmonis dalam sebuah lingkungan baik keluarga, masyarakat maupun negara. ${ }^{35}$

Karakter jujur sangat penting dimiliki oleh setiap orang. Memiliki karakter jujur akan membuat seseorang selamat dan dihormati oleh orang lain, memiki kewibawaan tinggi serta menjadi orang yang lebih bijaksana. Nanum jika nilai karakter jujur telah hilang pada diri seseorang maka kewibawaan, penghormatan dan kebikajsanaan yang dimilikinya akan dengan sendirinya punah dan tidak diakui lagi.

Masih banyak orang yang dalam dirinya belum terbentuk nilai jujur sebagai sebuah karakter sebagaimana pada tingkatan suara hati yakni pada bagian ke-tiga yang telah dijelaskan sebelumnya. Melainkan masih banyak orang yang jujur karena sebuah tekanan dari aturan maupun kurangnya godaan atau ujian untuk berbuat tidak jujur. ${ }^{36}$ Walau pada dasarnya kejujuran itu sangat dibutuhkan dalam hal apapun baik pekerjaan, bahkan dalam membangun suatu hubungan rumah tangga agar selalu harmonis serta kokoh maka sangat dibutuhkan sebuah kejujuran dalam diri manusia, terlebih lagi dalam beribadah kepada Allah SWT.

Manusia tentu tidak hanya dibutuhkan kejujurannya dalam kehidupan ini, namun juga rasa tanggung jawab dalam setiap amanah yang diberikan kepadanya, karena penciptaan manusia selain sebagai hamba Allah, manusia juga diberi amanah oleh Allah untuk mejadi khalifah di muka bumi, sebagaimana yang tertera dalam firma-Nya:

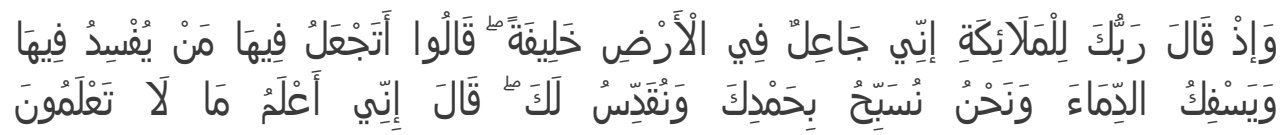

\footnotetext{
35 Hanafi, "Urgensi Penanaman Nilai Karakter Spiritual Keagamaan Dan Integritas Dalam Dunia Pendidikan," 146.

${ }^{36}$ Banyak orang datang ke bandara tidak telat karena aturan serta jadwal keberangkatan yang sudah ada, dan bukan karena karakternya untuk disiplin. Banyak orang tidak korupsi karena tidak ada celah atau kesempatan untuk korupsi, tapi jika ada kesempatan ya akan korupsi juga, walaupun dia keturunan orang sholeh bila nilai jujur itu belum sebagai karakter dalam dirinya maka bisa melakukan korupsi, kurang godaan yang diberikan. Disampaikan oleh Prof. Maragustam dalam kegiatan perkuliahan Pendidikan Nilai dan Spiritual Islam kelas reguler A, Pascasarjana, Psikologi Pendidikan Islam, UIN Sunan Kalijaga Yogyakarta, tanggal 10 April 2019.
} 
Nilai-Nilai Utama Karakter Spiritual Keagamaan Dan.....

Artinya: "ingatlah ketika Tuhanmu berfirman kepada Para Malaikat: "Sesungguhnya aku hendak menjadikan seorang khalifah di muka bumi." (Q.S al-Baqarah ayat 30). ${ }^{37}$

Jadi selain menjalankan tugas dan fungsinya sebagai hamba, manusia juga berperan sebagai pengelola semua sumber daya yang ada di bumi untuk kemaslahatan dan keberlangsungan hidup manusia itu sendiri. ${ }^{38}$ Amanah sendiri merupakan sesuatu yang ada dalam diri seseorang dan hal itu merupakan titipan, yang kemudian akan dipertanggungjawabkan kepada yang memberi amanah sesuai dengan aturan dalam penitipan itu. Sehingga dapat diartikan amanah adalah sesuatu yang dipercayakan kepadanya. Dengan nilai spiritual keagamaan seseorang yang kuat akan mampu mengemban amat itu dengan benar (jujur) serta mampu membawa kebahagiaan bagi orang lain dan juga mendapat ridha dari Allah SWT. Sehingga konsekuensi dari amanah itu dijaga dengan baik dan melekat dalam dirinya sebagai sebuah karakter, dalam arti ada ataupun tidak ada orang yang melihatnya jika dititipkan sesuatu maka dia selalu amanah. ${ }^{39}$

\section{Contoh Manusia Berkarakter Spiritualitas Islam dan Integritas Dalam Kisah Al- Qur'an}

Al-Qur'an sebagai kitab suci umat Islam sekaligus sebagai petunjuk bagi umat manusia, memiliki banyak sekali kisah-kisah yang mengandung nilai karakter spiritualitas keagamaan dan integritas yang patut untuk kita contoh, antara lain kisah yang terkait dengan keimanan yakni kisah dari Luqman al-Hakim dengan anaknya. Nilai karakter keimanan yang terdapat dalam surah Luqman adalah dari kata-kata la tusyrik billah sebagaimana dalam al-Qur'an yaitu:

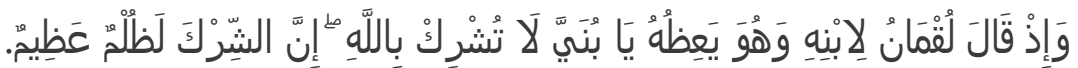

\footnotetext{
${ }^{37}$ Sudrajat, Syatibi, and Sidqi, Al-Qur'an Tajwid dan Terjemahnya Dilengkapi Dengan Asbabun Nuzul Dan Hadits Sahih, 6.

${ }^{38}$ Hanafi, "Urgensi Penanaman Nilai Karakter Spiritual Keagamaan dan Integritas Dalam Dunia Pendidikan," 146.

${ }^{39}$ Maragustam, Filsafat Pendidikan Islam Menuju Pembentukan Karakter Menghadapi Arus Global, 259.
}

Falasifa, Vol. 10 Nomor 2 September 2019 | 170 
Khairul Khalqi

Artinya: "dan (ingatlah) ketika Luqman berkata kepada anaknya, di waktu ia memberi pelajaran kepadanya: "Hai anakku, janganlah kamu mempersekutukan Allah, Sesungguhnya mempersekutukan (Allah) adalah benar-benar kezaliman yang besar". (Q.S. Luqman: 13). ${ }^{40}$

'Ali as-Sabuni menafsirkan la tusyrik billah yang dikutip oleh Hasibuan dengan menyatakan, jadilah orang yang berakal, jangan mempersekutukan Allah dengan apapun, apakah itu manusia, patung, atau benda lainnya. Selanjutnya beliau menafsirkan inna asysyirka lazulmun 'azim dengan mengatakan, perbuatan syirik merupakan sesuatu yang buruk dan tindakan kezaliman yang nyata. Karena itu siapa saja yang menyerupakan antara Khalik dengan Makhluk, tanpa ragu-ragu orang tersebut bisa dipastikan termasuk golongan orang yang paling bodoh, karena perbuatan syirik menjauhkan seseorang dari akal sehat dan dari hikmah, serta pantas digolongkan ke dalam sifat zalim, bahkan yang lebih parahnya lagi pantas disetarakan dengan binatang. ${ }^{41}$

Selain dengan penafsiran ini dapat juga kita melihat bagaimana sosok Luqman yang begitu lembut dalam mendidik anaknya, mengajarkan nilai karakter spiritual keagamaan yakni ketauhidan, dengan mengatakan janganlah menyekutukan Allah (syirik), karena tubuh adalah pemberian Allah, Allah-lah yang menciptakan langit dan bumi beserta isinya. Penanaman sifat ketauhidan ini akan sangat penting bagi seseorang, orang tua bagi anaknya, guru bagi muridnya bahkan pemerintah bagi rakyatnya.

Sebagai seorang muslim, kita tidak hanya bertanggungjawab kepada diri sendiri mengenai hal tersebut, melainkan juga memiliki tanggungjawab terhadap lingkungan sekitar, layaknya Luqman kepada anaknya. Dalam penanaman nilai spiritualitas keagamaan ma'rifatulah (tauhid) yang dilakukan Luqman kepada anaknya tidak hanya memperingati anaknya mengenai kesesatan bagi orang yang syirik. Tapi disini juga kita dapat melihat pendidikan yang dilakukan Luqman kepada anaknya yakni dengan mengajarkan kepada anaknya mengenai menjalankan syariat Islam, dengan menjalankan

\footnotetext{
${ }^{40}$ Sudrajat, Syatibi, and Sidqi, Al-Qur'an Tajwid Dan Terjemahnya Dilengkapi Dengan Asbabun Nuzul Dan Hadits Sahih, 412.

${ }^{41}$ Muslim Hasibuan, "Nilai-Nilai Pendidikan Karakter Dalam Kisah Al-Qur'an” (Disertasi, UIN Sunan Kalijaga Yogyakarta, 2015), 144-145.
} 
Nilai-Nilai Utama Karakter Spiritual Keagamaan Dan.....

ibadah shalat, menyeru dalam berbuat kebaikan, menghindari perbuatan yang dilarang oleh Allah, serta bersabar dengan apa yang menimpanya, sesuai dengan firman Allah SWT:

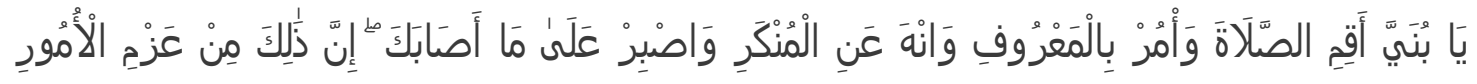

Artinya: "Hai anakku, dirikanlah shalat dan suruhlah (manusia) mengerjakan yang baik dan cegahlah (mereka) dari perbuatan yang mungkar dan bersabarlah terhadap apa yang menimpa kamu. Sesungguhnya yang demikian itu Termasuk hal-hal yang diwajibkan (oleh Allah)". (Q.S. Luqman: 17). ${ }^{42}$

Dari ayat di atas dapat kita lihat pendidikan yang dilakukan Luqman kepada anaknya dengan dengan mengajarkan kepada anaknya mendirikan shalat, setelah mendirikan shalat, pendidikan selanjutnya yakni mengerjakan perbuatan baik serta menghindari perbuatan yang mungkar, dan selanjutnya Luqman mengajarkan kesabaran atas apa yang ditimpakan oleh Allah kepada kita.

Kisah dalam al-Qur'an yang terkait dengan nilai karakter integritas antara lain digambarkan dalam kisah Nabi Yusuf A.S, sesuai dengan firman Allah SWT:

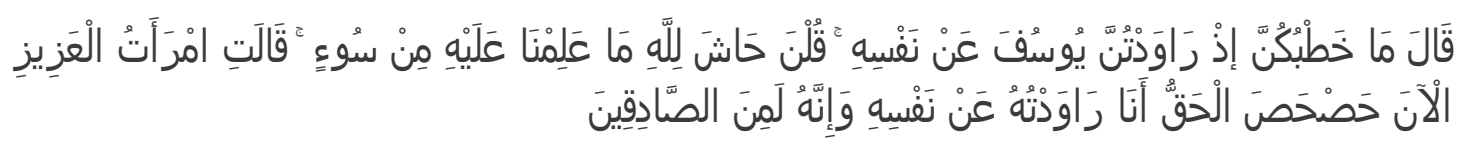

Artinya: Raja berkata (kepada wanita-wanita itu): "Bagaimana keadaanmu ketika kamu menggoda Yusuf untuk menundukkan dirinya (kepadamu)?" mereka berkata: "Maha sempurna Allah, Kami tiada mengetahui sesuatu keburukan dari padanya". berkata isteri Al Aziz: "Sekarang jelaslah kebenaran itu, Akulah yang menggodanya untuk menundukkan dirinya (kepadaku), dan Sesungguhnya Dia Termasuk orang-orang yang benar." (Q.S. Yusuf: 51). ${ }^{43}$

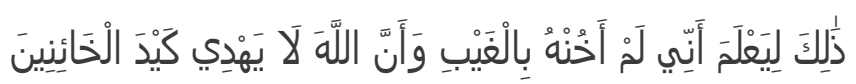

Artinya: (Yusuf berkata): "Yang demikian itu agar Dia (Al Aziz) mengetahui bahwa Sesungguhnya aku tidak berkhianat kepadanya di belakangnya, dan bahwasanya Allah tidak meridhai tipu daya orang-orang yang berkhianat. (Q.S. Yusuf: 52). ${ }^{44}$

Ayat ini merupakan kabar tentang Raja ketika ia mengumpulkan para wanita yang memotong-motong jarinya ketika melihat Nabi Yusuf di rumah istri al-Azis. Raja

${ }^{42}$ Sudrajat, Syatibi, and Sidqi, Al-Qur'an Tajwid dan Terjemahnya Dilengkapi Dengan Asbabun Nuzul Dan Hadits Sahih, 412.

${ }^{43}$ Ibid., 241.

${ }^{44}$ Ibid.

Falasifa, Vol. 10 Nomor 2 September 2019 | 172 


\section{Khairul Khalqi}

kemudian bertanya kepada para wanita tersebut yang pada hakikatnya pertanyaan ini ditujukan kepada istri al-Azis. Raja berkata kepada para wanita yang telah memotong jarinya itu "bagaimana keadaan kalian," yakni keadaan dan kabar kalian. Mereka berkata "maha sempurna Allah, kami tidak mengetahui sesuatu keburukan daripadanya'. Tidak mungkin Yusuf menjadi tertuduh, dan kami tidak mengetahui adanya keburukan pada diri Yusuf.” Kemudian istri al-Azis berkata, "kebenaran itu sudah jelas dan tampak. Aku yang menggodanya untuk mendudukkan dirinya (kepadaku), dan sesungguhnya dia termasuk orang-orang yang benar" yakni dia (yusuf) benar dalam perkataannya. ${ }^{45}$

Dengan penafsiran di atas dapat kita lihat betapa jujurnya Nabi Yusuf A.S, dalam berkata, bahkan dalam ceritanya sebelum kejujurannya terbukti dia tidak mau keluar dari dalam penjara. Dengan terbuktinya kejujuran itu maka ia (Yusuf) keluar dari penjara. Memiliki nilai karakter jujur akan membawa manusia pada derajat yang tinggi. Dengan rasa takut kepada Allah dan selalu merasa dalam pengawasan Allah akan membuat manusia terhindar dari perbuatan keji. ${ }^{46}$

Selain sifat jujur Nabi Yusuf A.S, juga memiliki sifat amanah yang patut kita jadikan sebagai contoh dalam kehidupan, baik saat kita menjadi pendidik, pemimpin dikalangan keluarga, bahkan sampai pada pemimpin negara. Sehingga jujur dan amanah ini sangat penting bagi kita. Sifat amanah Nabi Yusuf A.S, tergambar dalam firman Allah SWT:

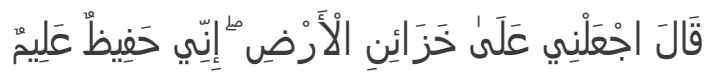

Artinya: Berkata Yusuf: "Jadikanlah aku bendaharawan negara (Mesir); Sesungguhnya aku adalah orang yang pandai menjaga, lagi berpengetahuan". (Q.S. Yusuf: 55). ${ }^{47}$

Dengan kepercayaan sang raja, kemudian Nabi Yusuf A.S, diberikan kedudukan dan amanah oleh raja, kemudian Nabi Yusuf A.S, memilih jabatan sebagai bendahara seraya memuji dirinya sendiri, dan hal itu diperbolehkan bagi seseorang apabila orang lain belum mengetahui urusannya, dan hanya sekedar untuk kebutuhan. Ibnu Katsir mengutip

\footnotetext{
${ }^{45}$ Imam Ibnu Katsir, Tafsir Ibnu Katsir (Jilid 5), Cet. 4 (Jawa Tengah: Insan Kamil Solo, 2017), 579-580.

${ }^{46}$ Hanik Mahliatussikah, "Analisis Kisah Nabi Yusuf Dalam Al-Qur'an Melalui Pendekatan Interdisipliner Psikologi Sastra," Journal of Arabic Studies Vol. 1, no. 2 (2016): 75-89.

${ }^{47}$ Sudrajat, Syatibi, and Sidqi, Al-Qur'an Tajwid Dan Terjemahnya Dilengkapi Dengan Asbabun Nuzul Dan Hadits Sahih, 242.
} 
Nilai-Nilai Utama Karakter Spiritual Keagamaan Dan.....

penjelasan dari Syaibah bin Nu'amah, ai berkata: “yakni pandai menjaga terhadap apa yang engkau titipkan kepadaku dan memiliki pengetahuan yang luas tentang masa-masa paceklik. $^{48}$

Sifat jujur dan amanah Nabi Yusuf A.S, terbukti dari berbagai perkara ataupun kejadian yang menimpa dirinya, sehingga dapat kita ambil pelajaran yang sangat berharga dari nilai karakter jujur dan amanah ini, yang dimana sifat ini sangat penting untuk dimiliki oleh manusia, dengan memiliki sifat ini maka kemuliaan maupun penghormatan akan diberikan kepadanya, karena sifat yang dimiliki. Penanaman sifat ini sangatlah penting kepada anak bagi orang tua, peserta didik bagi para guru, masyarakat bagi para tokoh, serta rakyat bagi para pemimpin negara.

\section{KESIMPULAN}

Dari pemaparan makalah di atas dapat disimpulkan bahwa nilai karakter spiritual keagamaan sangatlah penting dimiliki oleh manusia, yang dimana dalam nilai spiritual keagamaan manusia mengetahui penciptanya serta rasa berserah diri kepada Allah SWT. sebagai pencipta seluruh alam, sehingga dalam hal apapun dan dalam keadaan apapun selalu merasa takut hanya kepada Allah, berbuat kebaikan bukan karena ada orang lain yang melihatnya ataupun hanya karena undang-undang yang mengikatnya, melainkan berbuat karena Allah, begitu pula dengan meninggalkan perbuatan yang dilarang oleh Allah bukan karena kurangnya godaan terhadapnya melainkan meninggalkan karena takut dan patuh kepada Allah SWT.

Nilai karakter integritas, tentu sangat penting dan mendukung bagi kelangsungan hidup dimuka bumi sebagai makhluk yang terpilih oleh Allah menjadi Khalifah. Dalam berintraksi dengan sesama, baik dalam pekerjaan maupun dalam hal apapun, manusia dijadikan khalifah dimuka bumi ini merupakan sebuah amanah yang dititip oleh Allah dan akan dimintai penjelasan dari apa yang dilakukan selama hidupnya. Dengan memiliki karakter jujur dalam setiap perbuatan, seseorang akan menjadi lebih dihormati dan dipercaya oleh sesamanya. Dengan demikian dari kedua nilai karakter manusia ini dapat diambil pelajaran yang sangat bermanfaat dalam mendidik maupun menjalankan roda

\footnotetext{
${ }^{48}$ Ibnu Katsir, Tafsir Ibnu Katsir (Jilid 5), 582.
}

Falasifa, Vol. 10 Nomor 2 September 2019 | 174 
Khairul Khalqi

kehidupan di muka bumi ini, sehingga dari pengambilan nilai karakter ini kita dapat selamat baik di dunia maupun di akhirat nanti.

\section{DAFTAR PUSTAKA}

Ahmad Tafsir, Ilmu Pendidikan Dalam Perspektif Islam, Bandung: PT Remaja Rosdakarya, 2004.

Dwi S, Yohanes Probo. "Hubungan Antara Nilai Kejujuran Dan Pribadi Yang Otentik Dengan Perilaku Mahasiswa Universitas Bunda Mulia.” Psibernetika Vol. 8, no. 2 (2015): 138-149.

Fadillah. "Kejujuran Salah Satu Pendongkrak Pendidikan Karakter Di Sekolah.” Jurnal Visi Ilmu Pendidikan (n.d.): 968-980.

Gea, Antonius Atosokhi. "Integritas Diri: Keunggulan Pribadi Tangguh." Character Building Journal Vol. 3, no. 1 (2006): 16-26.

Hanafi, Imam. "Urgensi Penanaman Nilai Karakter Spiritual Keagamaan Dan Integritas Dalam Dunia Pendidikan.” An-Nuha Vol. 4, no. 2 (2017): 139-151.

Hasibuan, Muslim. “Nilai-Nilai Pendidikan Karakter Dalam Kisah Al-Qur'an.” Disertasi, UIN Sunan Kalijaga Yogyakarta, 2015.

Ibnu Katsir, Imam. Tafsir Ibnu Katsir (Jilid 5). Cet. 4. Jawa Tengah: Insan Kamil Solo, 2017.

Lapsley, Daniel K. and Darcia Nervaez, Character Education, (New York: Wiley).

Mahliatussikah, Hanik. “Analisis Kisah Nabi Yusuf Dalam Al-Qur'an Melalui Pendekatan Interdisipliner Psikologi Sastra.” Journal of Arabic Studies Vol. 1, no. 2 (2016): 7589.

Maragustam. Filsafat Pendidikan Islam Menuju Pembentukan Karakter Menghadapi Arus Global. Cet. 2. Yogyakarta: Kurnia Kalam Semesta, 2016.

—. Mencetak Pembelajar Menjadi Insan Paripurna. Yogyakarta: Nuha Litera, 2010.

an-Nawawi, Al-Imam, and Al-Hafizh Ibnu Rajab al-Hambali. Hadits Arba'in Nawawiyyah Plus (Matan Jami'ul-'Ulum Wal-Hikmah). Cet. 4. Yogyakarta: Maktabah Al-Hanif, 2009. 
Nilai-Nilai Utama Karakter Spiritual Keagamaan Dan.....

Sudrajat, Enang, Syatibi, and Abdul Aziz Sidqi. Al-Qur'an Tajwid Dan Terjemahnya Dilengkapi Dengan Asbabun Nuzul Dan Hadits Sahih. Bandung: Syigma Examedia Arkanleema, 2007.

Sukadari, Mahilda Dea Komalasari, and Ahmad Mabruri Wihaskoro. "Evektivitas Penanaman Nilai Integritas Pada Sisiwa SD Melalui Buku Wayang Pandawa Bervisi Antikorupsi." Integritas Vol. 4, no. 1 (2018): 217-244.

Zainuddin. Ilmu Tauhid Lengkap. Jakarta: Rineka Cipta, 1992. 